University of Nebraska - Lincoln

DigitalCommons@University of Nebraska - Lincoln

Faculty Publications from the Harold W. Manter Laboratory of Parasitology

6-1963

Echinococcus Infections in Man and Animals in Kenya

George S. Nelson

London School of Hygiene and Tropical Medicine

Robert L. Rausch

Arctic Health Research Center (Anchorage, Alaska), rausch@u.washington.edu

Follow this and additional works at: https://digitalcommons.unl.edu/parasitologyfacpubs

Part of the Parasitology Commons

Nelson, George S. and Rausch, Robert L., "Echinococcus Infections in Man and Animals in Kenya" (1963). Faculty Publications from the Harold W. Manter Laboratory of Parasitology. 517.

https://digitalcommons.unl.edu/parasitologyfacpubs/517

This Article is brought to you for free and open access by the Parasitology, Harold W. Manter Laboratory of at DigitalCommons@University of Nebraska - Lincoln. It has been accepted for inclusion in Faculty Publications from the Harold W. Manter Laboratory of Parasitology by an authorized administrator of DigitalCommons@University of Nebraska - Lincoln. 


\title{
ECHINOCOCCUS INFEGTIONS IN MAN AND ANIMALS IN KENYA
}

\author{
BY
}

\author{
GEORGE S. NELSON* \\ AND
}

ROBERT L. RAUSCH

(From the Medical Research Laboratory, Nairobi, Kenya, and the Arctic Health Research Center, U.S. Depariment of Health, Education and Welfare, Anchorage, Alaska)

(Received for publication Fanuary 26th, 1963)

More than 30 per cent. of the cattle, sheep and goats slaughtered in the central abattoir of the Kenya Meat Commission have hydatid cysts in either the liver or the lungs; the rate is even higher in animals slaughtered in the rural abattoirs (Ginsberg, 1958; Froyd, 1960). In spite, however, of the wide distribution in livestock, hydatids are rarely seen in man, except in the northern desert region of Turkana where the disease is particularly prevalent (Wray, 1958). Both Ginsberg and Wray suggested that this limited distribution might be explained if the main hosts of the parasite were hyaenas and jackals, not dogs. This hypothesis was supported by the absence of previous records of Echinococcus in dogs in East Africa.

In the present study on hydatid disease in Kenya, special emphasis was given to an assessment of the role of wild animals as reservoirs of the parasite. More than 100 carnivores were examined for the adult worms and nearly 2,000 miscellaneous animals were examined for the larval stages. Several wild animals were found to be lightly infected, but the main cycle of transmission was between dogs and domestic livestock. A few minor morphological differences were seen in the Kenya material, but it was concluded that the species in dogs and wild carnivores was Echinococcus granulosus.

\section{KENYA, GEOGRAPHICAL FEATURES}

Kenya lies on the Equator, but the climate is greatly modified by altitude and much of the country enjoys a Mediterranean-type climate. Even on the coast, where the mean annual relative humidity is around 80 per cent., the mean daily temperature is less than $80^{\circ} \mathrm{F}$.

The high-rainfall areas include the coastal strip, the highlands over 5,000 feet, and the western area near Lake Victoria; here, in less than a quarter of the land area, there are more than six million people out of a total population of approximately eight million. In many places the population density is more than I, ooo to the square mile (see map). The people are peasant farmers cultivating maize, millet, bananas, cassava and cash crops of coffee and cotton, but almost every homestead has a few cattle, sheep or goats, and usually at least one dog. Included in this area are the 'White Highlands.' Here, on the large European mixed farms, coffee plantations, tea estates and ranches almost one million Africans are employed. Most of the area over 8,000 feet is forest reserve.

The rest of Kenya has poor prospects of receiving more than 20 inches of rainfall a

* Now at the Department of Parasitology, London School of Hygiene and Tropical Medicine. 
year ; this is a region of grasslands, semi-desert and thorn scrub, much of it infested with tsetse flies and occupied by wild game. In the northern desert, and in Masailand and Turkana the people are nomadic. The Masai live in harmony with the great herds of antelopes, wildebeest, zebra, kongoni and gazelles which are preyed on by lions, hyaenas, hunting dogs and jackals. Hydatids are very common in their cattle and sheep but the people are only very occasionally infected. The Turkana live in a far less hospitable region, where there is little grass, most of the larger game animals have been eliminated, and there are very few wild carnivores. In this area hydatid cysts are common in both man and domestic animals.

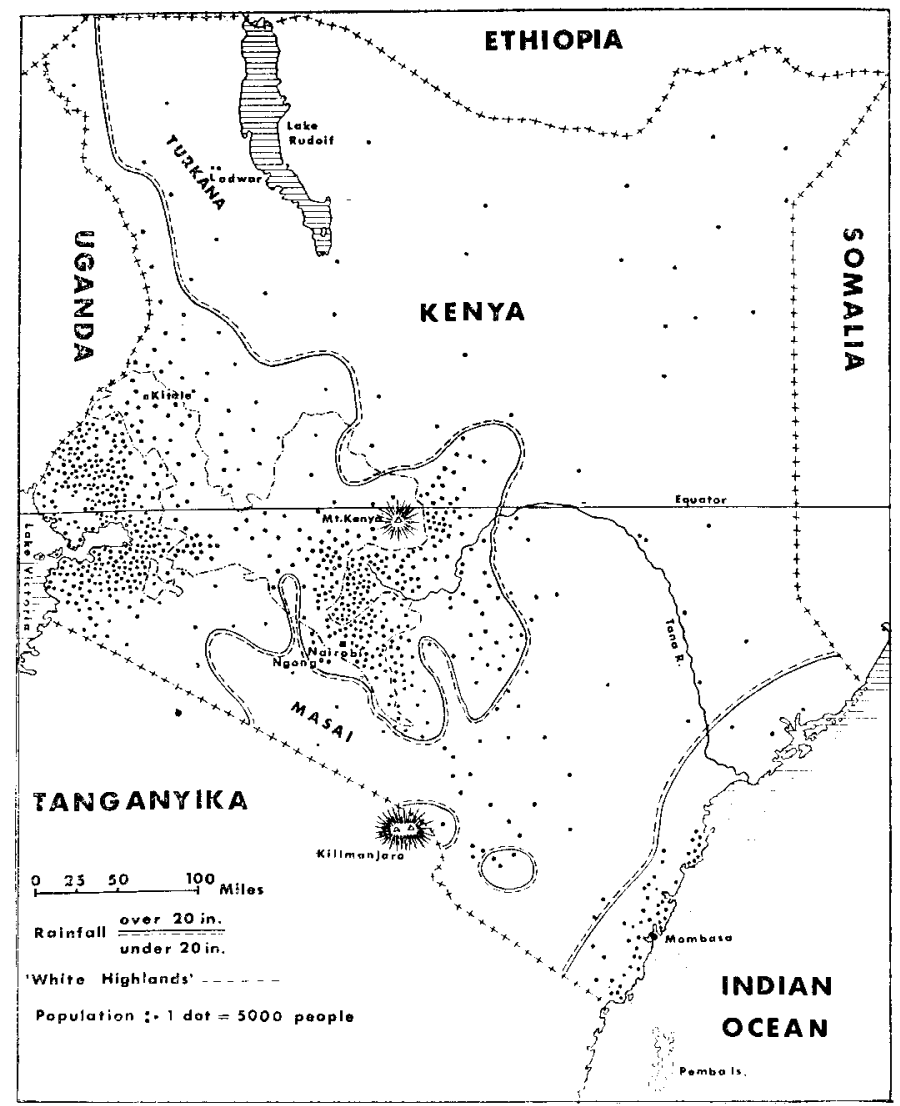

MAP of Kenya, showing geographical features.

MATERIALS AND METHODS

'The investigation was not specifically designed to study hydatid disease; it was the by-product of investigations on trichinosis, filariasis and bilharziasis. In those studies a wide range of animals was examined for parasitic infections and every opportunity was taken to examine the material for Echinococcus. The guts of dogs and wild carnivores were opened under water in large black-bottomed trays. If no worms were seen by 
direct inspection, the intestinal mucosa was scraped and the mucosal scrapings were examined after frequent washing and decanting. There was no difficulty in detecting light infections in dogs, even when dissections were made under field conditions, but it was not always easy to find adult Echinococcus in the milky calcareous bowel contents of hyaenas. It may be that a few light infections were missed in these animals. After washing in water, the adult worms were fixed either with alcohol as recommended by Vogel (1957) or by immersion in hot Io per cent. formol saline. Adult material from the domestic dog, hunting dog, jackal and spotted hyaena were studied in detail. The specimens were stained in Semichon's acetic carmine and mounted in toto. The rostellum was removed from representative samples and mounted separately, to facilitate measurement of the rostellar hooks. Morphological details were worked out primarily from the larger series from domestic dogs.

Available for direct comparison were series of E. granulosus, E. multilocularis, E. cameroni, E. oligarthrus, E. felidis and E. lycaontis. These had been stained as above and mounted in toto.

\section{CARNIVORES EXAMINED FOR ADULT ECHINOCOCCUS}

fackals. Sixteen jackals were examined; only one was found infected, a blackbacked jackal (Thos mesomelas). There are no previous records of natural infections in this species, although Viljoen (1937) experimentally produced a very heavy infection in one animal in South Africa. The golden jackal (T. aureus) has been found naturally infected in Palestine by Witenberg (I933) and in Ceylon by Dissanaike and Paramananthan (I960).

Hunting dogs. Three out of four hunting dogs (Lycaon pictus) were found to be lightly infected. In view of the records of Echinococcus from this animal in South Africa by Cameron (I926) and Ortlepp (I934), a special attempt was made to collect more hunting dogs, but they are now quite rare in East Africa and we failed to obtain more specimens.

Hyaenas. Three out of 19 spotted hyaenas (Crocuta crocuta) had very light infections. They came from the area where we found the infected jackal and hunting dogs; this was on a European cattle ranch in the Rift Valley near Mount Longonot, on the edge of the Masai reserve. There are no previous records of Echinococcus from the family Hyaenidae.

Lions and leopards. Apart from hunting dogs, the lion is the only other wild carnivore which has been found infected in Africa (Ortlepp, 1937). We examined four lions and three leopards from the Masai area; all were negative. E. granulosus has been reported from a lion in captivity by Porter (I943).

Miscellaneous carnivores. No infections were seen in any of the other species of carnivores (Table I). It is unlikely that Echinococcus adults will be found in genets, civets, servals and mongooses. These animals feed primarily on rodents, which we have not found infected with Echinococcus larvae although large numbers have been examined. The aard wolf (Proteles cristatus) and the bat-eared fox (Otocyon megalotis) are also unlikely hosts since both animals are mainly insectivorous. More wild carnivores must be examined from Kenya and elsewhere in Africa before concluding that they play no essential role as hosts of Echinococcus on the African continent.

Domestic dogs. Echinococcus infections were found in 27 out of 43 dogs (Canis familiaris - two out of five from Nairobi, three out of five from Ngong near an abattoir 
slaughtering Masai cattle, one each from two European farms in the Rift Valley, and one from a European farm Io miles south of Nairobi ; the rest (I9 out of 27 ) were from various parts of Turkana. Most of the infections were readily detected, but only in Turkana were the infections so heavy that the intestines were 'furred' with thousands of worms.

This is the first record of adult Echinococcus from Kenya. Hudson (I933), in his 'List of cestodes known to occur in East African mammals,' makes no mention of the adult worm.

TAJBLE I

Showing the carnivores examined for adult Echinococcus

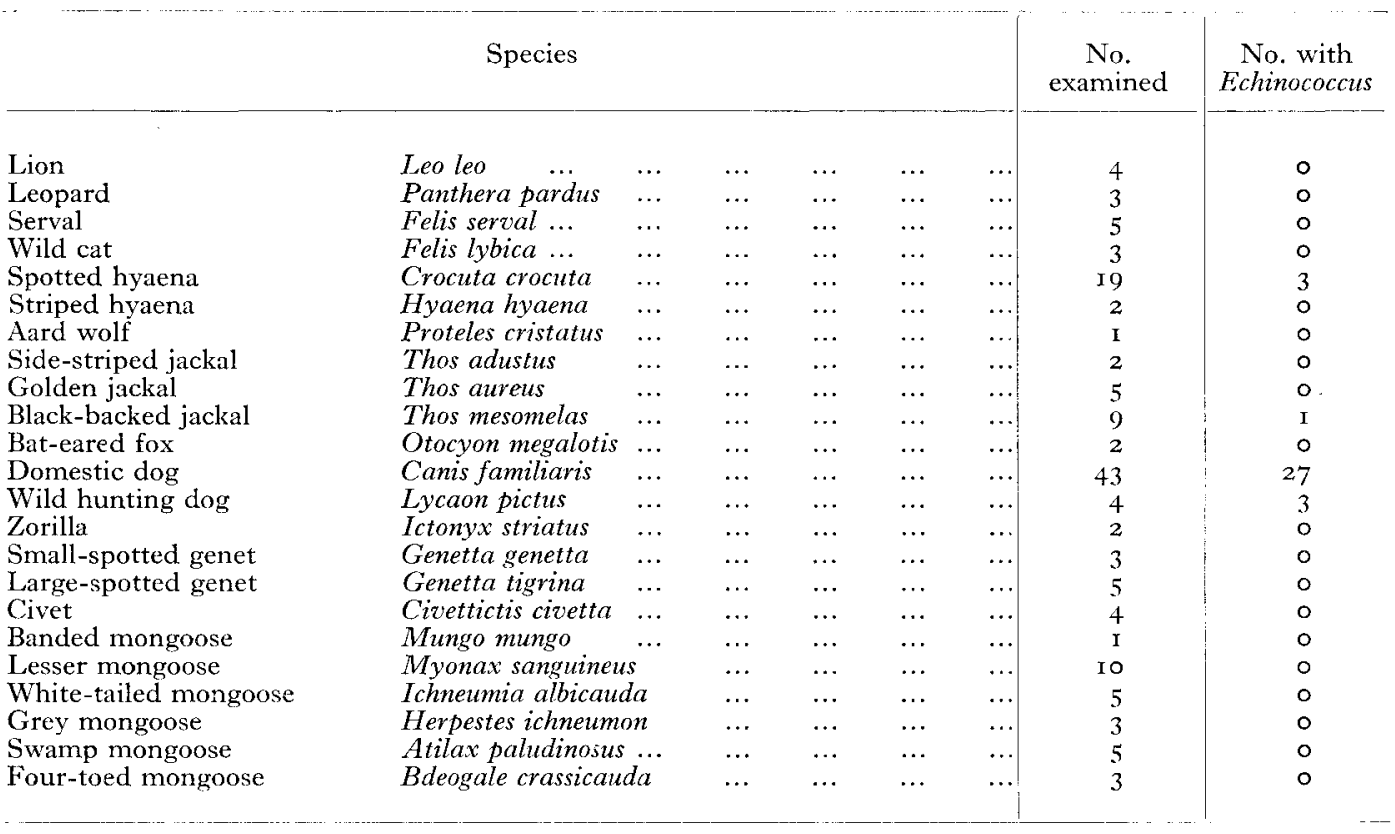

The Species of Echinococcus in Kenya

A detailed study of material from 12 of the infected carnivores shows that a single species of Echinococcus is present. The following description is based upon a large series of adult cestodes from domestic dogs from Ngong near Nairobi and from Lodwar in Turkana.

Length of strobila (with gravid segment) $2-3.5 \mathrm{~mm}$.; segments usually three in number, infrequently two or four. Genital pore near middle of segmental margin in mature segments, posterior to middle in gravid segments. Testes 45-49 in number (average of 20 segments 53), distributed from posterior end of segment, where they are confluent posterior to the vitelline gland and ovary, to near anterior margin of segment. Cirrus sac averages 1 Iо $\mu$ by $70 \mu$ in mature segments. Rostellar hooks $28-36$ in number, somewhat variable in shape. Large hooks measure $3 \mathrm{I}-45 \mu$ in length; small hooks measure $19-39 \mu$. Gravid uterus has lateral sacculations well developed.

Selected measurements are summarized in Tables II and III. A mature segment and rostellar hooks are shown in figs. I and 2. 
I40

A comparison of these cestodes with E. granulosus from other parts of the world disclosed no morphological differences which could be considered as significant at the species level (Tables II and III).

The Kenya cestode has a smaller strobila than that seen in other specimens of E. granulosus which have been available for comparison, but this character alone does not justify formal designation. We conclude that the species of Echinococcus occurring in Easî Africa is E. granulosus

TABLE II

Showing comparative measurements (in $\mathrm{mm}$.) of gravid segments of $E$. granulosus from Kenya and other sources

\begin{tabular}{|c|c|c|c|c|c|c|c|}
\hline \multirow{2}{*}{$\begin{array}{c}\text { Source } \\
\text { (and species) }\end{array}$} & \multirow{2}{*}{$\begin{array}{l}\text { No. } \\
\text { examined }\end{array}$} & \multicolumn{2}{|c|}{ Length of segment } & \multicolumn{4}{|c|}{$\begin{array}{l}\text { Position of genital pore } \\
\text { (from anterior margin of segment) }\end{array}$} \\
\hline & & Range & Mean & $\begin{array}{l}\text { Range of } \\
\text { distance }\end{array}$ & $\begin{array}{l}\text { Mean } \\
\text { distance }\end{array}$ & $\begin{array}{l}\text { Range } \\
\text { per cent. }\end{array}$ & $\begin{array}{l}\text { Mean } \\
\text { per cent. }\end{array}$ \\
\hline $\begin{array}{l}\text { Lodwar } \\
\quad \text { (C. familiaris })\end{array}$ & 93 & $I \cdot 37 I-2 \cdot 378$ & $\mathrm{I} \cdot 773$ & $0.728-1 \cdot 406$ & 0.980 & $4^{8-62}$ & 55 \\
\hline $\begin{array}{l}\text { Ngong } \\
\text { (C. familiaris) }\end{array}$ & 24 & $I \cdot 285^{-2} \cdot 363$ & $\mathrm{I} \cdot 8 \mathrm{I} 3$ & $0.785-1 \cdot 535$ & $I \cdot 058$ & $54-75$ & $5^{8}$ \\
\hline $\begin{array}{l}\text { Alaska } \\
\quad(C . \text { familiaris })\end{array}$ & $2 I$ & $I \cdot 856-3 \cdot 249$ & $2 \cdot 560$ & $0.942-I \cdot 82 I$ & $I \cdot 4 I 2$ & $5^{I-59}$ & 55 \\
\hline $\begin{array}{l}\text { Alaska } \\
\quad(\text { C. lupus })\end{array}$ & 24 & $2 \cdot 37^{8-3} \cdot 177$ & $2 \cdot 772$ & $I \cdot 335^{-2} \cdot 092$ & I. 684 & $55^{-76}$ & $6 \mathrm{I}$ \\
\hline $\begin{array}{l}\text { Argentina } \\
\text { (C. familiaris })\end{array}$ & 16 & $I \cdot 042-2 \cdot 499$ & $\mathbf{I} \cdot 87 \mathrm{I}$ & $0.649^{-I} \cdot 35^{6}$ & $I \cdot 06_{3}$ & $5^{\circ}-64$ & 57 \\
\hline $\begin{array}{l}\text { Germany* } \\
\quad(\text { C. familiaris })\end{array}$ & 27 & $1 \cdot 020-1 \cdot 830$ & $I \cdot 430$ & - & - & - & - \\
\hline $\begin{array}{l}\text { Germany* } \\
\text { (C. familiaris })\end{array}$ & $2 \mathrm{I}$ & $I \cdot 780-3 \cdot 200$ & $2 \cdot 400$ & - & - & $\left(\begin{array}{c}55^{-6} 63 \\
(20 \text { segments })\end{array} \mid\right.$ & 59 \\
\hline $\begin{array}{l}\text { Jugoslavia* } \\
\text { (C. familiaris) }\end{array}$ & 22 & $1 \cdot 630-2 \cdot 300$ & $2 \cdot 000$ & - & - & $\left(\begin{array}{ll}12 & 50-61 \\
\text { segments }\end{array}\right)$ & $55 \cdot 5$ \\
\hline
\end{tabular}

*Data from Vogel (1957).

The relatively few specimens available from the indigenous carnivores closely resembled those from domestic dogs. The cestodes from hunting dogs were typical in development. Those from the single infected jackal had no gravid segments, but the material was too limited in amount to warrant any conclusion as to the suitability of the jackal as a host of $E$. granulosus. The I5 cestodes from a spotted hyaena had no eggs in the large terminal segments but the uterus was well developed. The single specimen from a second hyaena, however, had a gravid uterus containing about 90 eggs, to all appearances normally developed. Hyaenas are widely separated phylogenetically from the canids and may be unsatisfactory hosts for $E$. granulosus, but this and other questions can best be solved by controlled experimental infections. 
TABle III

Showing comparative measurements (in $\mathrm{mm}$.) of the rostellar hooks and cirrus sac of E. granilosus from Kenya and other sources

\begin{tabular}{|c|c|c|c|c|c|c|c|c|c|c|c|}
\hline \multirow{3}{*}{$\begin{array}{c}\text { Source } \\
\text { (and species) }\end{array}$} & \multicolumn{6}{|c|}{ Rostellar hooks } & \multirow{2}{*}{\multicolumn{5}{|c|}{ Cirrus sac }} \\
\hline & \multicolumn{3}{|c|}{ Large hooks } & \multicolumn{3}{|c|}{ Small hooks } & & & & & \\
\hline & $\begin{array}{c}\text { No. } \\
\text { measured }\end{array}$ & $\begin{array}{l}\text { Range of } \\
\text { length }\end{array}$ & $\begin{array}{l}\text { Mean } \\
\text { length }\end{array}$ & $\begin{array}{c}\text { No. } \\
\text { measured }\end{array}$ & $\begin{array}{l}\text { Range of } \\
\text { length }\end{array}$ & $\begin{array}{l}\text { Mean } \\
\text { length }\end{array}$ & $\begin{array}{l}\text { No. } \\
\text { measured }\end{array}$ & $\begin{array}{c}\text { Range of } \\
\text { length }\end{array}$ & $\begin{array}{l}\text { Mean } \\
\text { length }\end{array}$ & $\begin{array}{l}\text { Range of } \\
\text { width }\end{array}$ & $\begin{array}{l}\text { Mean } \\
\text { width }\end{array}$ \\
\hline $\begin{array}{l}\text { Lodwar } \\
\quad \text { (C. familiaris) }\end{array}$ & 287 & $0.032-0.040$ & 0.036 & $22 \mathrm{I}$ & $0.019-0.03 \mathrm{I}$ & 0.026 & 63 & $0.097-0.1_{3} 8$ & 0.110 & $0.055-0.079$ & 0.067 \\
\hline $\begin{array}{l}\text { Ngong } \\
\quad(\text { C.familiaris })\end{array}$ & $6 I$ & $0.03 I-0.045$ & 0.040 & 52 & $0.021-0.039$ & 0.029 & 12 & $0.102-0.121$ & 0.110 & $0.050-0.071$ & 0.059 \\
\hline $\begin{array}{l}\text { Alaska } \\
\quad(\text { C.familiaris })\end{array}$ & IOI & $0.032-0.040$ & 0.036 & 8 r & $0.024-0.03 \mathrm{I}$ & 0.027 & 34 & $0.08 \mathrm{r}-0.134$ & 0.108 & $0.065-0.097$ & 0.085 \\
\hline $\begin{array}{l}\text { Alaska } \\
\quad \text { (C. lupus) }\end{array}$ & 68 & $0.039-0.045$ & 0.040 & 60 & $0.023-0.03 \mathrm{I}$ & 0.025 & 22 & $0.121-0.154$ & 0.145 & $0.073-0.089$ & 0.082 \\
\hline $\begin{array}{l}\text { Argentina } \\
\quad \text { (C. familiaris) }\end{array}$ & 35 & $0.027^{-0.036}$ & $0.03 \mathrm{I}$ & 44 & $0.018-0.030$ & 0.024 & - & - & - & 一 & - \\
\hline $\begin{array}{l}\text { Australia } \\
\quad(\text { C. familiaris })\end{array}$ & 249 & $0.029-0.037$ & 0.033 & 260 & $0.014-0.032$ & 0.022 & - & 一 & - & - & - \\
\hline
\end{tabular}


I 42

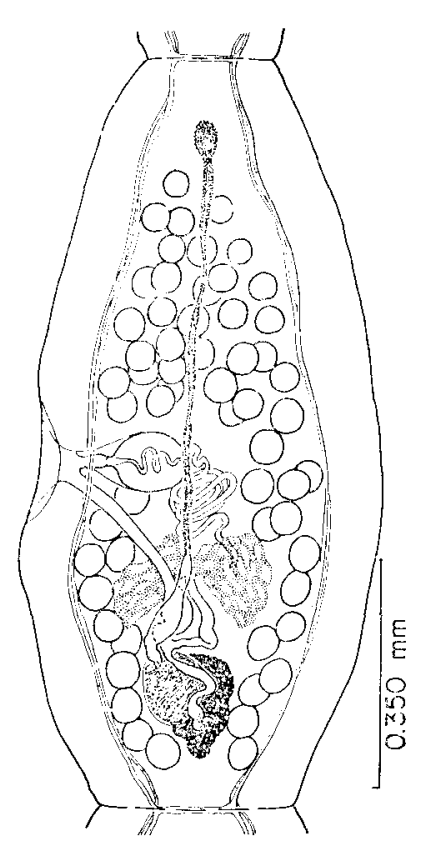

FIG. I. Mature segment of E. granulosus from a domestic dog, Rongai, Kenya.
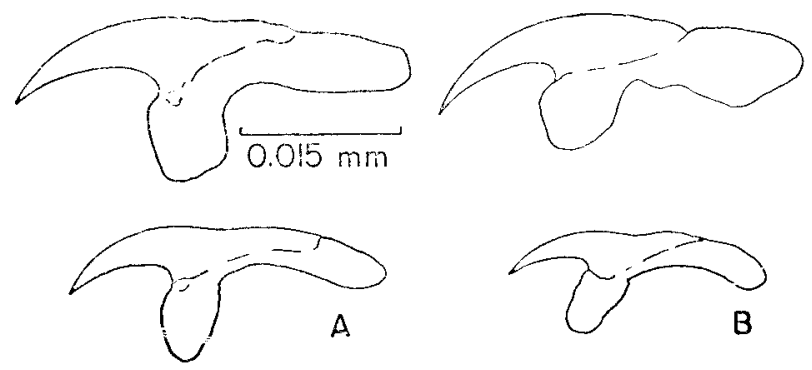

FIG. 2. Rostellar hooks of E. granulosus. A, from a domestic dog, Lodwar, Turkana, B, from a domestic dog, Ngong, Kenya. (Much variation in shape was noted, even on single cestodes.)

\section{MISCELLANEOUS ANIMALS EXAMINED FOR HYDATID CYSTS}

Ungulates. If $E$. granulosus or other species of Echinococcus were prevalent in the wild animals of Africa, the most likely hosts of the larval stages would be the ungulates which cccur in large herds in various parts of the continent, particularly in East Africa. We have examined 92 ungulates, representing i 8 species (Table IV); most of the animals came from the Masai plains, where they share the grazing with numerous cattle, sheep and goats, which are heavily infected with hydatids. The commonest animal in this area is the wildebeest (Gorgon taurinus), followed by the zebra (Equus burchellii), the impala (Aepyceros melampus), the gazelles (Gazella granti and G. thomsoni), the wart-hog 
I43

TABLE IV

Showing the miscellaneous animals examined for hydatid cysts

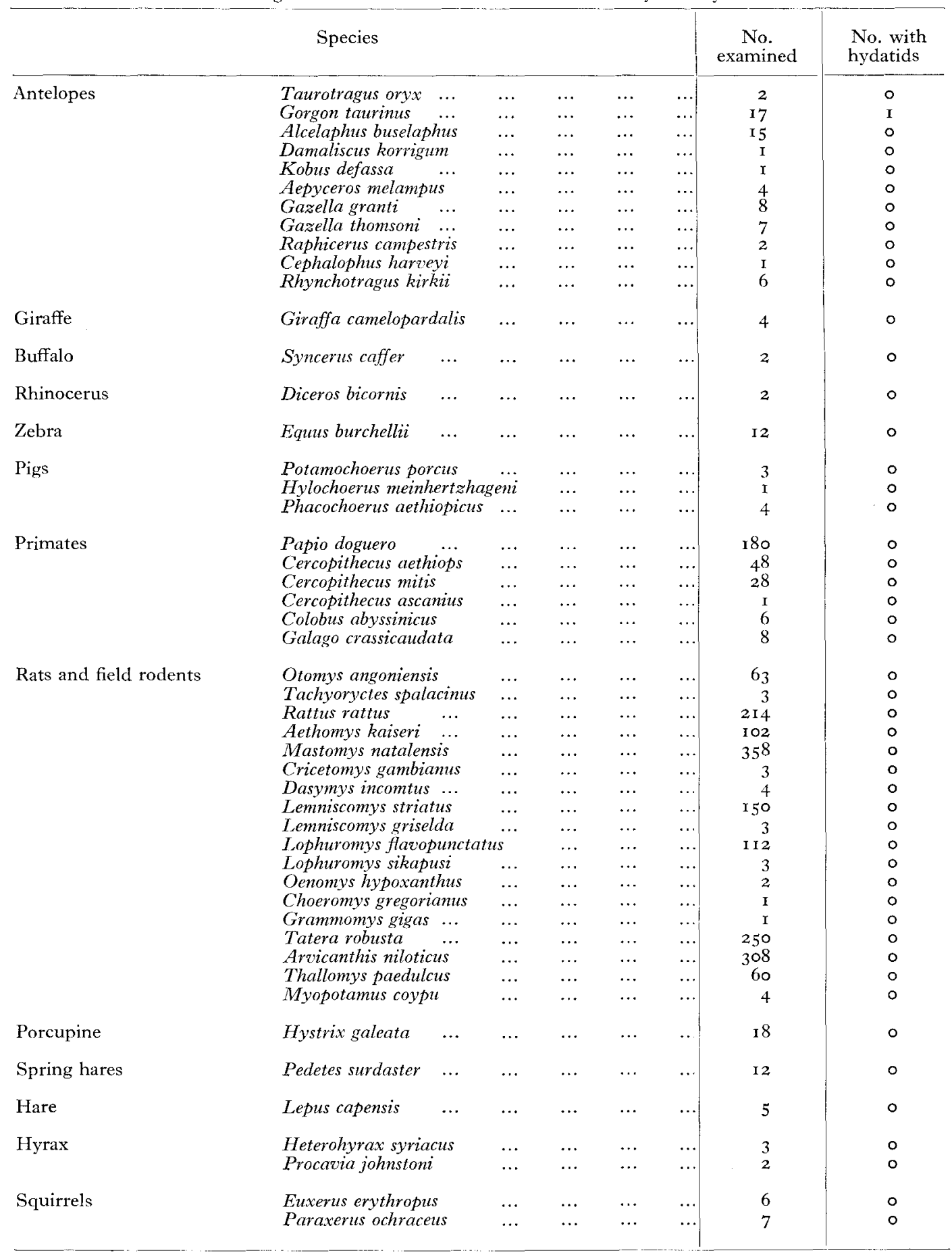


144

(Phacochoerus aethiopicus), and the giraffe (Giraffa camelopardalis). Cysts of other cestodes, such as Taenia hydatigena, T. hyaena or T. crocuta, were common in most of the antelopes, but hydatids were found in only a single wildebeest. In this animal there were two fertile cysts in the lungs. No hydatid cysts were found in various antelopes examined by Urquhart et al. (1960) elsewhere in Kenya or by LeRoux (1957) in Rhodesia. In fact, nowhere have hydatid cysts been found to be prevalent in antelopes, although many of these animals have been examined by veterinarians and parasitologists elsewhere on the continent.

Rodents and miscellaneous small animals. Altogether, I,674 small mammals were examined. A high percentage of Rattus rattus had Cysticercus fasciolaris in the liver. A polycephalid larva was commonly seen in the liver of Mastomys natalensis from the Coast Province. This larval cestode was similar to that described from West Africa by Southwell and Kirshner (1937), who believed it to be an aberrant C. fasciolaris. A similar larva has been seen in the Congo, and Mahon (1954) has suggested that it is the larval stage of T. parva, a common cestode of the genet cat. A coenurus was found in Otomys angoniensis and in a porcupine (Hystrix galeata) from Mount Kenya. But no rodents were infected with Echinococcus larvae. It is known that rodents are not normally susceptible to E. granulosus infections, but they are the main intermediate host of E. multilocularis, the species producing the relatively rare alveolar hydatids in man in Europe and in the Arctic regions of America and Siberia. This species is maintained in nature by a cycle of transmission between wild carnivores and rodents (Rausch and Schiller, I954; Vogel, I957). Our failure to find hydatids in small animals suggests that E. multilocularis is absent from Kenya and that rodents are unlikely to be hosts of other species of Echinococcus in this part of the world.

Non-human primates. Occasionally hydatid cysts are seen in captive monkeys. Allen (1957) describes a case in Macaca philippinensis and refers to seven previous records, some of which may have been acquired in nature. Dissanaike (1958) found cysts in $M$. sinica in India.

We examined $27 \mathrm{I}$ wild primates in Kenya; they were all negative.

\section{HYDATID CYSTS IN MAN}

The cases of hydatid disease recorded in the annual reports of the Kenya Medical Department have been reviewed by Wray (1958), who operated on 25 patients in Kitale hospital. One hundred and seventeen cases were notified between $195^{2}$ and I955; more than half the patients were Turkana tribesmen. Sixty-four cases were recorded at Kitale between 1957 and I96I (Cummins, personal communication). Kitale is in the European farming area, but the hospital serves part of the northern desert region, including Turkana, and Cummins says that, "although it is not possible to give the tribe in each case, it is reasonably certain that all were 'Turkana.' Dr. Fernandes, at Lodwar hospital in the centre of Turkana country, saw 18 hydatids in 1960 and 24 in $1961 ; 32$ were transferred to Kitale for operation and are included in Dr. Cummins's figures. Turkana is one of the most primitive parts of Africa ; it has a nomadic population of about 80,000 people, with 200,000 cattle, 800,000 sheep and goats, 96,000 donkeys and 80,000 camels (Gulliver and Gulliver, 1953). In the local hospital no special diagnostic 
facilities are available and chest X-rays are not performed. There have been no hydatid surveys. Only people who are obviously ill, usually with enormous abdominal cysts, are diagnosed. In this very extensive area, where there is only one doctor, many asymptomatic cases must occur, and deaths from the disease must be quite common in places that are unaffected by the medical services. The same is probably true in Masailand.

Elsewhere in Kenya hydatids are much less prevalent. Only 55 cases were seen in the four-year period 1958-6I at the King George VI Hospital in Nairobi ; this is the largest hospital in the country, where the equipment is up-to-date and there are specialist facilities, including a thoracic surgery unit serving all the outlying areas.

No satisfactory explanation can be given for the comparative rarity of the disease in man in the major ranching areas where there is a high incidence in livestock. It is noticeable that there is no record of a European with hydatid disease, in spite of the intimate contact between children and dogs on practically every farm. The disease is also uncommon in the Ukambani native reserves, where the people use dogs for hunting.

In Turkana, in the hot desert area, there are no permanent houses and no cultivation; here conditions are, at first sight, far less suitable for transmission from dogs to man than in many other parts of Kenya. We know, however, that in Turkana dogs are very heavily infected, and they are very numerous, with at least one dog to every family. There is also a high cyst rate in the domestic animals, including the numerous camels, which, according to El-Kordy (1946), are excellent hosts of the parasite, with more than 60 per cent. of the cysts fertile.

It has been shown by Schwabe and Daoud (1961) that hydatids can be prevalent in a community because of a peculiar local custom. Shoemakers in the Lebanon are infected because they use dog faeces in tanning leather. It is a widespread belief that the Turkana will eat practically anything, including dogs, and it was considered that they might be infected by eating the highly infectious intestines of dogs, since they regard the intestines of most animals as a great delicacy. But, when questioned, they emphatically denied that they eat carnivores, and this is confirmed by Gulliver and Gulliver (1953). Their normal food, which consists of a mixture of cow's blood and milk, is not likely to be contaminated by dog faeces, but the wild berries which are gathered after the rainy season may possibly be a source of infection.

The most likely explanation of the high rate in this area is the intimate contact from a very early age between the numerous dogs and children. The dogs are encouraged to eat the excreta of babies, and they are used to clean up the mess by licking the child's face and anal regions when a child vomits or has diarrhoea. The dogs sleep with the children in the very primitive thorn-and-skin shelters, where there is no attempt at domestic cleanliness. They often feed from the same utensils. It seems probable that this close intimacy between dogs and children is an important factor, explaining the higher rate of hydatid disease in the Turkana than in the more advanced tribes of East Africa. As Barnett (1939) has noted, 'a hydatid cyst is in most cases nearly as old as the patient.'

It is most unlikely that wild animals play any part in the transmission of hydatid disease in this area. In comparison with other parts of Kenya, Turkana has a very sparse game population. It is noticeable that in the two major townships of Lodwar and Lokitaung there were no hyaenas or jackals, whereas in Masailand hyaenas are plentiful around even the smallest township. 


\section{Control}

It is perhaps premature to formulate plans for the control of hydatid disease in Kenya, but even on present evidence it is clear that this is a public health and economic problem of considerable importance. There is little doubt that the disease could be considerably reduced by relatively simple measures.

A good deal of money and effort is expended each year on the control of rabies. Livestock officers are employed to register and vaccinate dogs, and ownerless dogs are destroyed. Since it seems likely that dogs are the main source of Echinococcus infections in Kenya, campaigns against rabies could be combined with the control of hydatid disease, and priority should be given to reducing the surplus dog population in Turkana.

In other areas, where hydatid disease is uncommon in man, considerable wastage of essential protein results from the high condemnation rate of the cystic livers from cattle, sheep and goats. All this could be avoided if the staff of the rural health centres were encouraged to co-operate with veterinarians in a campaign against the disease.

Experience in advanced countries like New Zealand has shown that treatment of dogs with anthelminthics is expensive and not altogether effective. In less-developed countries such as Kenya, control would be more readily effected by improvement in meat hygiene, by the destruction of all unregistered dogs, and by an active health-education campaign. The problem may seem formidable, but the successful eradication of hydatid disease in Iceland suggests that the problems are not insuperable (Dungal, I957).

\section{DISCUSSION}

Parasitologists working in Africa are mainly employed in dealing with urgent and obvious problems; only in recent years, with the successful control of many parasitic diseases, have opportunities been found to investigate conditions which are apparently of little clinical significance. Distribution-maps of hydatid disease, such as the one produced by Cameron and Webster (1959), suggest that the parasite is rare or absent over much of tropical Africa. From the figures which we have quoted, however, it is obvious that, far from being rare, hydatid disease in man and livestock is more prevalent in Africa than in many other parts of the world. The same is true of trichinosis; until quite recently Trichinella was thought to be non-existent in Africa. We now know that it is common in man, bush-pigs and wild carnivores in many parts of East Africa (Nelson, Guggisberg and Mukundi, in preparation). Our preliminary studies have shown that hydatid disease is an important problem. Further studies with radiological and serological techniques are required to determine the prevalence of the disease in man.

In most parts of the world E. granulosus is a parasite maintained by a cycle of transmission between dogs and other domestic animals. The most important intermediate hosts are usually sheep and goats, but horses, cattle, camels, pigs and reindeer have been found infected. In the United States of America, Canada and Alaska there is a cycle between the wolf and the moose (Riley, 1933; Miller, I953; Rausch, 1952), and there is evidence that the parasite is transmitted between jackals and wild deer in Ceylon (Dissanaike and Paramananthan, 1960, 196r). In Australia, a secondary E. granulosus cycle occurs between the dingo and the wallaby (Durie and Riek, 1952). In Africa, where carnivores and their food hosts are more prevalent than in any other part of the world, one might expect that conditions would be ideal for the transmission of E. granulosus amongst 
wild animals, and also for the evolution of different species of Echinococcus. Three species have, in fact, been described from wild carnivores in South Africa : E. longimanubrius and E. lycaontis were described by Cameron (1926) and by Ortlepp (1934) from the hunting dog L. pictus (syn. L. capensis), and Ortlepp (1937) described E. felidis from the lion. In each instance the material was obtained from only one animal. We have had an opportunity of examining some of the South African material and we consider that these 'species' are probably all aberrant forms of $E$. granulosits (Rausch and Nelson, 1963). There are no further records of adult worms from African wild carnivores, and there are no records incriminating wild herbivores as important intermediate hosts. Our observations indicate that dogs are, in fact, the main hosts of E. granulosus in Kenya, with the larval stage in cattle, sheep, goats and camels. The few adult worms seen in hunting dogs, hyaenas and the jackal, and the fertile cyst seen in the wildebeest, probably represent incidental infections of no significance in the maintenance of the parasite in nature.

Like many other organisms, helminths show a great deal of infraspecific variation, but it is only in recent years that strain differences have been recognized as being of significance in the epidemiology of helminthic diseases. Some biological variants are well recognized among helminths infecting man; these include Ascaris lumbricoides, Wuchereria bancrofti, Schistosoma japonicum and Hymenolepis nana, but they are not exceptions. The ubiquitous Trichinella spiralis, which has long been regarded as a uniform species, is now known to show considerable variations ; a strain isolated in Kenya is of very high infectivity to man but of very low infectivity to rats (Forrester, Nelson and Sander, I96r). Similar variations in infectivity and pathogenicity have been recognized in the genus Echinococcus by Vogel (1957), Shul'ts (1962) and Cameron (1960). Dissanaike and Paramananthan (1961) have recently described a variant of E. granulosus in Ceylon which is characterized by extraordinarily large numbers of scolices in the brood capsules in the hydatid cysts, although no morphological differences were seen in the adult material.

The morphological variations seen in Kenya Echinococcus indicate that there may be unusual strains of E. granulosus in East Africa. This could account for the exceptionally high prevalence of fertile cysts in Kenya cattle as reported by Froyd (1960), and it might explain the prevalence of the parasite in the hot arid areas, whereas elsewhere in the world the parasite seems better adapted to cooler regions with a higher rainfall (Gemmell, I960). It is also possible that in most parts of Kenya the parasite is relatively poorly adapted to man, and that a different strain of higher infectivity exists in Turkana. The next step in these Echinococcus investigations in Kenya will be to study the biological properties of the parasite in the laboratory, by isolating strains from different animals in different parts of the country for comparison with material from other parts of the world.

\section{SUMMARY}

I. Hydatid cysts are found in more than 30 per cent. of all cattle, sheep and goats in Kenya, but the disease is prevalent in man only in the semi-desert area of Turkana. Up to the time of the present investigation the life-cycle of the parasite in East Africa had not been studied, but it was suggested that wild carnivores, such as hyaenas and jackals, might be the main hosts of the adult worms.

2. One hundred and forty-three carnivores, representing 23 species, have been examined. Echinococcus adults were found in 27 out of 43 domestic dogs (Canis familiaris), 
148

in three out of four hunting dogs (Lycaon pictus), in one out of nine jackals (Thos mesomelas), and in three out of 19 hyaenas (Crocuta crocuta).

3. A detailed morphological study was made of the Kenya material. After comparison with specimens from other parts of the world, it was concluded that the only species occurring in Kenya was E. granulosus, but it is possible that the minor morphological and biological differences are evidence of distinct strains. Further laboratory studies are necessary to compare the parasite from man and animals in different parts of Kenya with material from elsewhere.

4. A search was made for larval hydatids in 92 ungulates representing 18 species, and in a miscellaneous collection of nearly 2,000 rodents and primates representing a further 3 I species. Only one animal was positive, a wildebeest (Gorgon taurinus).

5. The infections in the wild carnivores were all very light; only domestic dogs were heavily infected. It is concluded that the main cycle of transmission in Kenya is between dogs and domestic livestock.

6. Turkana tribesmen are the most heavily infected people in Kenya, either because the strain of parasite is more pathogenic to man in that area, or, more probably, because of the intimate contact between children and the large number of infected dogs. A particularly dangerous custom in the area is the use of dogs to clean the face and anal regions of babies when they vomit or have diarrhoea. No satisfactory explanation can be given for the rarity of the disease in man in many of the other areas of Kenya where hydatids are very common in domestic animals.

7. The control of the disease will depend upon an active health-education campaign, together with the destruction of all unregistered dogs and improvement in meat hygiene.

Acknowledgements.--We are grateful to all officers of the Game Department and National Parks who have co-operated in this investigation. We are particularly indebted to Mr. Stephen Ellis, of the Royal Nairobi National Park, and to Mr. McCabe, of the Kenya Game Department. Mr. C. A. W. Guggisberg has generously assisted with the identification of the mammals. This work would have been impossible without the technical assistance of Mr. Roy Rickman, Mr. Alphonse Kipkiruri and Mr. F. R. N. Pester, who helped with the collection and dissection of many of the animals.

Comparative material utilized in the study was made available through the generous co-operation of Dr. 'T. W. M. Cameron, of the Institute of Parasitology, McGill University, Quebec ; Dr. R. J. Ortlepp, Division of Veterinary Services, Department of Agriculture, Pretoria; Dr. Jean G. Baer, Institut de Zoologie, Université de Neuchâtel ; Dr. Masashi Ohbayashi, Faculty of Veterinary Science, Hokkaido University, Sapporo; and Dr. Benjamin D. Blood, Oficina Sanitaria Panamericana, Buenos Aires. The contribution of these persons is gratefully acknowledged.

\section{REFERENCES}

Allen, A. M. (1957). Pulmonary hydatid disease in a rhesus monkey. Arch. Path., 64, I48. BARNETT, Sir L. (1939). Hydatid disease: errors in teaching and practice. Brit. med. $\mathscr{F} ., 2,593$.

Cameron, 'T. W. M. (1926). Observations on the genus Echinococcus Rudolphi, r8or. F. Helminth., 4, 13. (I960). The incidence and diagnosis of hydatid cyst in Canada, Echinococcus granulosus var. canadensis. Parassitologia, 2, $38 \mathrm{r}$.

and WeBster, G. A. (1959). Hydatidosis-Echinococcus. Bull. epiz. Dis. Afr., 7, 17. 
Dissanaike, A. S. (1958). On hydatid infection in a Ceylon Toque monkey Macaca sinica. Ceylon vet. F., 6, 33 . and Paramananthan, D. C. (1960). On the occurrence of Echinococcus granulosus (Batsch, I786) in a Ceylon jackal. Ibid., 8, 82 .

$35,221$.
Dungal, N. (1957). Eradication of hydatid disease in Iceland. N.Z. med. $F ., ~ 56,213$.

Durie, P. H., and RIEK, R. F. (I952). The role of the dingo and wallaby in the infestation of cattle with hydatids (Echinococcus granulosus (Batsch, 1786) Rudolphi, 1805) in Queensland. Aust. vet. F., 28,249 .

EL-Kordy, M. I. (I946). On the incidence of hydatid disease in domestic animals in Egypt. $\mathcal{F}$. Egypt. med. Ass., $29,265$.

Forrester, A. T.' T., Nelson, G. S., and Sander, G. (1961). The first record of an outbreak of trichinosis in Africa south of the Sahara. Trans. R. Soc. trop. Med. Hyg., 55, 503.

Froyo, G. (r960). Cysticercosis and hydatid disease of cattle in Kenya. \%. Parasit., 46, $49 \mathrm{I}$.

Gemmell, M. A. (1960). Advances in knowledge on the distribution and importance of hydatid disease as world health and economic problems during the decade r950-1959. Helminth. Abstr., 29, 355 .

Ginsberg, A. (1958). Helminthic zoonoses in meat inspection. Bull. epiz. Dis. Afr., 6, I4I.

Gulliver, P., and Gultiver, P. H. (I953). The central Nilo-Hamites. (Ethnographic Scenes of Africa, pt. VII.) Lond. : Int. Afr. Inst.

Hudson, J. R. (1933). A list of cestodes known to occur in East African mammals, birds and reptiles. F. E. Afr. Ug. nat. Hist. Soc., 49-50, 205.

LeRoux, P. (I 957). The control of parasitic disease in livestock. Rep. F.A.O., no. 696.

Mahon, J. ( ( 954). Tapeworms from the Belgian Congo. Ann. Mus. Congo belge, Zool. Sćr. 5, I, i 37.

Miller, M. J. (1953). Hydatid infection in Canada. Canad. med. Ass. F., 68, 423.

Neison, G. S., Guggisberg, C. A. W., and Mukundi, J. (in preparation). Animals hosts of Trichinella spiralis in East Africa.

Ortlepp, R. J. (r934). Echinococcus in dogs from Pretoria and vicinity. Onderstepoort 7. vet. Sci., 3, 97. (1937). South African helminths. pt. I. Ibid., 9, 311.

Paramananthan, D. C., and Dissanaike, A. S. (1960). Sylvatic Echinococcus infection in Ceylon. [Correspondence.] Trans. R. Soc. trop. Med. Hyg., 54, 601.

Porter, A. (1943). Report of the Honorary Parasitologist for 1932. Proc. zool. Soc. Lond., II3, 16I.

Rausch, R. L. (1952). Hydatid disease in boreal regions. Arctic, 5, I 57. and Nelson, G. S. (rg63). A review of the genus Echinococcus Rudolphi, I80r. Ann. trop. Med. Parasit., 57, I27.

and Schillilir, E. L. (1954). Studies on the helminth fauna of Alaska. XXIV: Echinococcus sibiricensis n.sp., from St. Lawrence Island. F. Parasit., 40, 659 .

Rilex, W. A. (1933). Reservoirs of Echinococcus in Minnesota. Minn. Med., r6, 744.

Scrwarie, C. W., and Daoud, K. A. (196I). Epidemiology of echinococcosis in the Middle East. I : Human infection in Lebanon, I949 to 1959. Amer. F. trop. Med. Hyg., I0, 374.

SIIUL'TS, R. S. (1962). [On the epidemiology of echinococcosis and methods of its control.] (In Russian ; English summary.) Med. Parasit., Moscow. 31, 272.

Southwell, T., and Kirshrer, A. (1937). Description of a polycephalic cestode larva from Mastomys erythroleucus, and its probable identity. Ann. trop. Med. Parasit., 31, 37.

Urquhart, G. M., Hay, D., Zaphiro, D. R. P., and Spinage, C. A. (1960). Some internal parasites of game animals in Kenya. "E. Afr. agric. $\mathscr{7}, \mathbf{2 6}$, $\mathbf{1}$.

Viljoes, N. F. (I937). Cysticercosis in swine and bovines, with special reference to South African conditions. Onderstepoort $\mathcal{F}$. vet. Sci., 9, 337.

VOGEL, H. (1957). Über den Echinococcus multilocularis Süddeutschlands. I: Das Bandwurmstadium von Stämmen menschlicher und tierischer Herkunft. Z. Tropenmed. u. Parasit., 8, 404.

Witenibrg, G. (1933). Zur Kenntnis der Verbreitung von Echinokokkus und Trichinen in Palästina. Arch. Schiffs- u. Tropenhyg,, 37, 37.

WRAY, J. R. (1958). Note on human hydatid disease in Kenya. E. Afr. med. F., 35, 37. 